\title{
Comparative Religion and its Vicissitudes in an Age of Globalization ${ }^{1}$
}

\author{
MORNY JOY \\ University of Calgary
}

\begin{abstract}
This article is a survey of some of the major challenges that have been directed at Comparative Religion during the last forty years. A number of these regard such an orientation as simply a construction that is a product of a scholar's imagination. Others regard it as exhibiting a distinctly western, specifically Christian influence that is dismissive of other religions. Nonetheless, there have been attempts to redress this imbalance and challenge biased categories and interpretations. In this regard, much can be learnt from postcolonial and women scholars, as well as from other disciplines such as anthropology. Nonetheless in contemporary times, the exploits from globalization threatens to have a disruptive influence on the discipline.
\end{abstract}

Keywords: comparative religion, postcolonialism, orientalism, critical approaches, cultural essentialism, globalization, Jonathan Z. Smith, Edward Said, James Clifford

I would like to introduce this topic by outlining my own specific location - of both an academic and social nature. This is because what I am saying might not always be applicable to Finland - or even Europe - given my present geographical location in North America. But I do believe that there are some obvious dominant trends in contemporary scholarship that merit attention if comparative religion is to continue in a vibrant and constructive manner. Given these developments, I would like to position myself as a scholar of Comparative Religion who, since I began my doctoral studies approximately thirty-five years ago, has witnessed a drastic change in this discipline. I realize that in the space allotted for this discussion, I cannot

1 Parts of this essay previously appeared in Method and Theory in Religious Studies: Retrospect and Future Prospects. Temenos, 2008, 43(2), 65-88, as well as in After Appropriation: Explorations in Intercultural Philosophy and Religion. Calgary: University of Calgary Press (2013). Both reprinted with permission. 
cover such an expanse of time and diversity of material in great depth, but after presenting some of the main changes, I plan to assess where we stand today and what needs to be done.

\section{Jonathan Z. Smith}

I would situate the beginning of these changes in Comparative Religion - although others may decide on different landmarks - with Jonathan Z. Smith's essay originally presented in 1972, 'A Map Is Not a Territory'. In this paper Smith launched the first major critical appraisal of Comparative Religion, specifically the idealist, romantic version, especially as it was then conducted under the auspices of what was then called 'the Chicago school'. The major orientation was a study of the meanings of myth, symbol and ritual - but it was its theoretical and methodological framework of a quasi-historical and phenomenological nature that attracted most criticism. Smith's position, then, needs to be understood as located with a broader understanding of what then constituted the field of the study of religion, as well as its mode of study. Smith gives his own definition of religion near the beginning of his paper:

Religion is the quest, within the bounds of the human, historical condition, for the power to manipulate and negotiate one's 'situation' so as to have 'space' in which to meaningfully dwell. It is the power to relate one's domain to the plurality of environmental and social spheres in such a way as to guarantee the conviction that one's existence 'matters'. Religion is a distinctive mode of human creativity, a creativity which both discovers limits and creates limits for humane existence. (Smith 1978, 291.)

Smith then continues with specific reference to scholars of religion: 'What we study when we study religion is the variety of attempts to map, construct and inhabit such positions of power through the use of myths, rituals and experiences of transformation' $(1978,291)$. In Smith's view, however, it is not only the adherents of a specific religion, but also the scholars of religion who both create and in diverse ways inhabit a meaningful cosmology. Smith further elaborates:

In most cases one cannot escape the suspicion that, in the locative map of the world, we are encountering a self-serving ideology which ought not to be generalized into the universal pattern of religious experience and expression $(1978,293)$. 
Yet this is what Smith perceives as happening with marked regularity. 'I find the same conservative, ideological element strongly to the fore in the variety of approaches to religion which lay prime emphasis upon congruency and conformity, [...]. Therefore it has seemed to me of some value, in my own work, to explore the dimensions of incongruity that exist in religious materials' (Smith 1978, 293). This is because Smith views the understanding of myth involved in such a conservative setting as severely limited:

Those myths and rituals which belong to a locative map of the cosmos labour to overcome all incongruity by assuming the interrelatedness of all things, the adequacy of symbolization, and the power and possibility of repetition (Smith 1978, 292).

It is hard to escape the suspicion that, in this context, it is Mircea Eliade who is Smith's principal target. In Smith's work, Eliade appears as a classic example of a scholar who seeks to apply congruity in his interpretations of myth, and thus avoids facing the incongruities that Smith considers as a necessary task. Smith then continues by offering a close reading with alternative possible interpretations of a number of myths discussed by Eliade (Smith 1978, 296). But Smith has something else of greater import in mind. He is quite explicit in his denunciation of the binaries and the exclusions that have resulted from such congruent interpretations; for not only have they 'skewed both our interpretative strategies and the formulation of our hermeneutic categories' $(1978,298)$, but they also have 'prevented us from realizing what is human and humane in the worlds of other men' (1978, 297). As a result, such studies are deficient and even dehumanizing.

On the conceptual level it robs them of their humanity, of those perceptions of discrepancy and discord which give rise to the symbolic project that we identify as the very essence of being human. It reduces the primitive to the level of fantasy where experience plays no role in challenging belief, but where discrepancy does not give rise to thought but rather is thought away. (Smith 1978, 297.)

Smith is equally severe in his indictment of the earliest studies of a comparative nature. This was because he detected an implicit understanding, in both the nineteenth and twentieth centuries, that a distinction was made between those who are the makers of history, and those who aren't. Or, even more blatantly, between those who are the makers of history and who merit the 
name of human and, on the other side, those who are classed as non-human and simply endure history as objects.

This observation sets up the terms of an early intractable dualism of 'us' and 'them'. Yet Smith is also unimpressed by the changes that he has detected in the studies in the 1960s and early 1970s, such as those of Eliade. Here the tendency is more to 'idealize' the primitive other, who remains nonetheless 'primitive'. Smith observes:

What troubles me is that these two portraits of the primitive - the nineteenth century negative and twentieth century positive (even nostalgic) appreciation - are but two sides of the same coin. They are but variations on an even older ambivalence: the Wild Man and the Noble Savage. Both interpretations take the primitive's myths literally, and believe him to do the same, the nineteenth century holding that anyone who believes such stuff is a fool, a child or subhuman; the twentieth arguing that the myths are true, yet another kind of truth from what we commonly recognize. (Smith 1978, 297.)

\section{Postcolonialism}

Both these designations are equally problematic in Smith's eyes, as they indicate the western imperious and colonizing gaze, even in its self-serving romanticizing guise. Smith's work advances many of the criticisms that were developed, beginning in the 1980s, by a number of Indian scholars, who coined the term 'postcolonialism'. Examples of those voicing such concerns and advocating both in-depth analysis and alternative historical viewpoints regarding India and 'Hinduism' include: Veena Das (1986), Asis Nandy (1983), Dipesh Chakrabarty (1992), R. Radhakrishnan (1996), Kumkum Sangari and Sudesh Vaid (1990), Romila Thapar (1989), Uma Chakravarti (1989) and Partha Chatterjee (1989). It was the work of Edward Said, however, that first made an impact on western scholarship.

\section{Edward Said}

In western scholarship, it was perhaps Edward Said's book, Orientalism (1978), published in the same year as Smith's volume, that launched a public awareness of what could be regarded as 'cultural supremacy', an attitude adopted by certain westerners in the study of other cultures. 'Orientalism', the term which Said used, refers to a western or Eurocentric projection of its fears and fantasies onto countries, societies and religions that are 
deemed exotic. As a phenomenon, such a movement is not confined to the 'Orient', i.e., only Near Eastern Islamic cultures, as in Said's book, but can be applied to similar attitudes to Asia, Africa, Central and South America. Postcolonialism, as an off-shoot of this awareness, in turn puts into question the imposition of cultural stereotypes on a country or peoples who have been subjected to the influence of European imperialism. Both these repudiations - orientalism and postcolonialism - reject any pattern of representation made in accordance with a dominant and reductive Eurocentric principle. And although the anthropological theorist James Clifford, among other commentators, detects that Said's depictions of the 'Orient' oscillate between two inconsistent interpretations of the term: (1) as an actual entity, the 'Orient' that is being distorted, and (2) as a figment of Western imagination, he nevertheless believes that Said's basic message is both cogent and adequate for application in other domains, such as his own, anthropology.

The key theoretical issue raised by Orientalism concerns the status of all forms of thought and representation for dealing with the alien. Can one ultimately escape procedures of dichotomizing, restructuring, and textualizing in the making of interpretive statements about foreign cultures and traditions? If so, how? (Clifford 1988, 261.)

One of the first western scholars to take heed of Said's work and apply it to India was Ronald Inden, a professor of History at the University of Chicago. In his article 'Orientalist Constructions of India' (1986), and then in his later book Imagining India (1990), similarly to Smith, Inden took to task both scholars who romanticized India and those who used denigrating and/or reductionist language. His collection of romantics included Ananda Coomaraswamy, Stella Kramrisch, Mircea Eliade, as well as C. G. Jung, Heinrich Zimmer and Joseph Campbell (Inden 1986, 432). In evaluating their problematic descriptions, he charges that:

The adherents of the romantic view, best exemplified academically in the discourses of Christian liberalism and analytic psychology [...] insist that India embodies a private realm of the imagination and the religious which modern, Western man lacks but needs. They [...] have a vested interest in seeing that the Orientalist view of India as 'spiritual', 'mysterious', and 'exotic' is perpetuated (Inden 1986, 442.)

Inden viewed this attitude as a version of the 'perennial philosophy', rendering 'Hinduism' as an essentialist and universal view of religion. In this 
way the ordinary Hindu became an exemplar of homo religiosus. Inden is also concerned that this type of hypostatization indicates that the human spirit, psyche or mind is a unitary, and identical item $(1986,434)$. Yet Inden is just as severe in his comments regarding the misrepresentations that he believes occur when Western empirical and scientific studies are imposed on the Indian tradition. This alternative version of Orientalism, as Inden explicates, appears to drain the lifeblood from living subjects in a quest for exact knowledge, while also rendering them as incapable of attaining the higher levels of western intelligence. '[T] he Orientalist, known nowadays as an "area studies specialist", appears as rational, logical, realistic, and objective. The knowledge of the Orientals, by contrast, often seems irrational, illogical, unscientific, unrealistic and subjective.' (Inden 1986, 408.) This is a damning indictment of western arrogance.

\section{Further Critical Assessments}

Numerous books and essays by other western scholars over the past twentyfive years since Smith, Said, and Inden have witnessed to the fact that all too often the perceived task in the initial description of other religions had been one of simply reducing the religion being discussed to the concepts and approaches of Western scholarship. This has led to numerous books that demonstrate the mistaken descriptions, impositions of inappropriate western terms, if not the fabrications of certain religions: e.g., Philip Almond (1988); David Chidester (1996); Donald Lopez (1998); Richard King (1999); and Hugh Urban (2003). Timothy Fitzgerald (2000) alleges that there is also a dominant thread of Protestantism that informs many of the offered definitions and interpretations of the non-Christian religions. He even expands his charge of such influence, somewhat incongruously, to include the continued impact of a conglomerate he names as the 'Western-capitalist-liberalecumenical-democratic hegemony' $(2001,113)$, which he posits as also being dependent on this 'Protestant ethic'. The Indian scholar, S. N. Balagangadhara, had first charged such Christian influence in his work, The Heathen in his Blindness (1994), where he proposed that even the term 'religion' was a foreign importation and thus a misrepresentation. In addition, the Sikh scholar, Arvind-Pal Mandair, in Religion and the Specter of the West (2009), has expertly described how the legacy of western colonial scholarship with its 'mono-theo-lingualism' still pervades and distorts much of contemporary Asian attempts to free themselves from it. Although the vehemence of some of these positions has been disputed, there remains sufficient evidence to 
support certain allegations of misappropriation, particularly in the case of the indigenous peoples.

\section{James Clifford}

Some scholars in Comparative Religion have looked to other disciplines such as anthropology to learn from the insights that were beings garnered there. One of the most influential critical anthropologists was James Clifford, who, in his book, The Predicament of Culture (1988), virtually undertook an ethnography of western culture itself. Central to his searching investigation were questions that probed far beyond the reach of anthropology: 'Who has the authority to speak for any group's identity and authenticity? What are the essential elements and boundaries of a culture? How do self and "the other" clash in the encounters of ethnography, travel, and modern interethnic relations?' (Clifford 1988, 8.) This was indicative for Clifford of a specific crisis in his own discipline, evident in his declaration that there was 'a pervasive postcolonial crisis of ethnographic authority' $(1988,8)$. He came to regard an anthropologist not so much a detached observer, but rather as one who situates him- or herself within a historically constituted world, only too aware that one's own worldview is similarly subject to such variable and shifts as those one studies. As stated in Joy $(2000,132)$, Clifford acknowledges the seemingly paradoxical modes of engagement in ethnography as it both negotiates and evaluates the very procedures it both introduces and participates in. This self-reflective stance, which scrutinizes one's own presuppositions, would seem to provide a distinctly appropriate model for scholars in Religious Studies. Clifford is committed to an awareness of the multiple and entangled roles and voices that are played out in any dynamic encounter. No single universal model of interpersonal or culturally biased assessment will suffice:

These studies suggest that white ethnographic writing cannot entirely escape the reductionist use of dichotomies and essences, it can at least struggle self-consciously to avoid portraying abstract, ahistorical 'others'. It is more than ever crucial for different peoples to form complex concrete images of one another, as well as of relationships of knowledge and power that connect them; but no sovereign scientific method or ethical stance can guarantee the truth of such images. They are constituted - the critique of colonial representation has shown at least this much - in specific historical relations of dominance and dialogue. (Clifford 1988, 23.) 


\section{Women's Perspectives}

Brilliant as Clifford's reflections might be, he has still been challenged by women scholars as to his omission in not including their own particular struggles in negotiating this terrain. Kamala Visweswaran (1994) one of Clifford's students, has suggested ways in which his work could be both improved and qualified by women's articulation of their own views. Nonetheless, Clifford does appear to acknowledge his awareness of the dominance of male voices, even if he does not offer insights as to a greater participation of women. He says:

With expanded communication and intercultural influence, people interpret others, and themselves, in a bewildering diversity of idioms - a global condition of what Mikhail Bakhtin called 'heteroglossia'. Yet heteroglossia is not a ready-made solution. It assumes voices, most likely male ones; and does not confront problems of coming to voice. (Clifford 1988, 38.)

It was only in the last decade of the twentieth century, however, that a number of books by women on postcolonialism and religion began to appear. These include: Laura Donaldson (1992), Laura Donaldson and PuiLan Kwok (2002), Musa Dube (2002), Ursula King and Tina Beattie (2003), Pui-Lan Kwok (2005), Sylvia Marcos (2006; 2010) and Morny Joy (2000; 2003; 2008; 2012; 2013). Nonetheless, scholars such as Rita Gross (1977) and Diane Bell (1994) had earlier alerted scholars to the gender bias that existed in Comparative Religion itself. In her 1977 essay, 'Androcentrism and Androgyny in the Methodology of the History of Religions' (1977, 7-21), Gross had identified an exclusiveness in language and a privileging of the male perspective in Eliade's work. Diane Bell, in her study, Daughters of the Dreaming (1994), analyzed how Durkheim's categories of sacred and profane had been employed to assign Australian aboriginal women to the category of profane - implying that they had no rituals and myths that merited being studied. She intimated this was the result of western male scholars' own somewhat circumscribed attitudes toward western women. (Bell 1994, 236, 242-48.)

It is also noteworthy in this context that even Edward Said was noticeably reticent about the exclusion or stereotyping of women. In her study of Turkish women, Julie Marcus observes:

In his book Orientalism (1978), Said documents the European obsession with women and oriental sexuality, but he does so incidentally, as part of 
the process by which the oriental was constructed as an objectified other, unable to speak as an individual and known only through the European writer. [...] The important role of women and sexuality in the structuring of western discourse on the east is a matter he doesn't dwell upon, and thus obscures the centrality of women and sexuality to the totality of orientalist knowledge. (Marcus 1992, 40.)

In recent years more women's voices have been added to the mix, but there remains one tantalizing question as to whether women scholars, as they come into their own, can avoid the traps of previous generations and, so to speak, avoid the sins of the fathers? As a woman scholar, there are a number of other scholars, both male and female, whose work I often call upon to help undertake such analyses as recommended above from various perspectives, as it appears that there are a number of different critical implements that need to be deployed - both in the self-reflexivity required in the writing of any textual material about other religions, and in the task of interpretation that makes use of strategies such as Ricoeur's hermeneutics of suspicion, critical theory, or discourse analysis. In what follows I will suggest some names of scholars who have been of assistance to me in my work.

\section{Critical Approaches}

The words of the anthropologist Talad Asad are particularly pertinent as a beginning. He recommends that a thorough survey needs to be undertaken of religion's modernist historical inheritance. This, however, should not be construed as simply reductive, viewing all religion phenomena only as social constructs; what is required is a thorough contextual study, which is extremely relevant for comparative religion:

From this it does not follow that the meanings of religious practices and utterances are not to be sought in religious phenomena, but only that their possibility and authoritative status are to be explained as products of historically distinctive disciplines and forces. The anthropological student of particular religions should therefore begin from this point, in a sense unpacking the comprehensive concepts which he or she translates as 'religion' into heterogeneous elements according to its historical character. (Asad 1993, 54.)

Another such scholar is the American historian and critical theorist, Joan Scott, who proposes that the following questions concerning gender need to be asked of any text: 
How and under what conditions [have] different roles and functions been defined for each sex; how [have] the very meanings of the categories 'man' and 'woman' varied according to time and place; how [were] regulatory norms of sexual deportment created and enforced; how [have] issues of power and rights played into questions of masculinity and femininity; how [do] symbolic structures affect the lives and practices of ordinary people; how [were] sexual identities forged within and against social prescriptions. (Scott 1999, xi.)

Since Scott wrote these words, there have been debates concerning the viability of the term 'gender' as well as questions about sexual dimorphism, but for a basic reading of important historical religious material, and even contemporary debates, such questions are always revealing of presuppositions. This is especially true of comparative studies, where I think that these questions still carry sufficient weight to help unravel imposed religious rules and proclamations, often of a prescriptive nature. This is particularly helpful in deciphering cases of false attribution of western terms and concepts.

A third critic who has contributed very valuable insights to discussions concerning the study of other religions cultures but, at the same time, even of her own, is Uma Narayan. In her book Dislocating Cultures: Identities, Traditions and Third World Feminism (1997), and an essay, 'Essence of Culture and a Sense of History' (1998), Narayan eloquently discusses the topic of essentialism - both of gender and of culture. In her analysis, gender features as a conventional ideal which, in most traditional societies, demands a specific code of conduct. There is indeed the notion of performativity, as described by Judith Butler (1990), in a manner that entrenches specific womanly conduct and punishes aberrations. As such, it is also accepted as a cultural norm that dates 'from time immemorial'. In such cultures, there is no place for contestation. Narayan describes this situation as 'gender essentialism'.

Narayan dramatically describes her own personal experience with her mother, who became very disapproving of her challenging the traditional roles. She is puzzled by her mother's seemingly contradictory stance in trying to inculcate gender norms of a 'good Indian woman', while at the same time being very supportive of her education, which enabled her to perceive the duplicity of the culture's treatment of women and challenge it $(1997,7)$. Narayan has no time for either 'gender essentialism' or 'cultural essentialism'. She compares the two: 
While gender essentialism often equates the problems, interests, and locations of some socially dominant groups of men and women with those of 'all men' and 'all women', cultural essentialism often equates the values, worldviews and practices of some socially dominant groups with those of 'all members of the culture' (Narayan 1998, 88).

Narayan is equally concerned about 'the national and cultural identity agenda' of Hindu nationalism and the mobilization of women in the cause of a pan-Indian womanhood. Ostensibly operating in the cause of cultural and national authenticity, the appeal of cultural essentialism in this context presents a pristine version of Hinduism, often termed 'Hindutva', that purportedly dates back to Vedic times. She states:

We need to be wary about all ideals of 'cultural authenticity' that portray 'authenticity' as constituted by lack of criticism and lack of change. We need to insist that there are many ways to inhabit nations and cultures critically and creatively. (Narayan 1997, 33.)

Finally, Narayan will argue that such historical essentialist depictions of cultures also obscure the degree to which what is viewed as constitutive of a particular 'culture', and central to projects of 'cultural preservation', do change over time. She views essentialist notions of culture as all too often relying on presenting cultures not only as 'givens' but as 'unchanging givens'. This denies the reality of historical change, and the political interests with which it is entwined. Such disclaimers also promote a static and 'fixed' picture of cultures, as if they were immune to history. To counter such cultural essentialism, Narayan suggests a process of 'cultural analysis', in a manner that is similar to that of Joan Scott. What she views as necessary is an informed historical understanding of the contextual pressures, particularly religious and political ones. This approach will always place cultural traditions, together with gender, in question, especially those cultures that adopt defensive positions..

It is extremely important to keep the above critique in mind in any undertaking that tries to establish less self-preoccupied ways of describing and evaluating constructions of religion. But there also needs to be a wariness, especially when certain constructions only serve to disseminate not simply false data but also deliberate dissimulation, as proposed by Hindutva's appeal to an idealized Vedic era. 


\section{Other Strategies}

Another strategy that can be applied is to bring together like-minded people for workshops and conferences to mull over the present difficulties that best Comparative Religion. One experiment was a workshop called After Appropriation: Explorations in Intercultural Philosophy (Joy 2013). It brought together a group of leading scholars in the two fields of what has been called 'comparative religion' and 'comparative philosophy'. The unique aspect of the workshop was that this was perhaps the first time that a group of scholars had been intentionally assembled who had expertise in both areas, of comparative philosophy and comparative religion. The mandate was to explore the current state of affairs in these fields and to explore whether there can be a rapprochement between them. To further this task, it set out to investigate certain problems and/or to suggest alternative approaches. While there were already numerous specialized books in the particular fields of comparative philosophy and of comparative religion, there are only a limited number of scholars who can address both disciplines. Another concern that presented itself was how to address the past distortions that had affected the descriptions of religions by those whose own primary affiliation was Christianity. To this end, the title of the workshop was deliberately chosen to attempt to move beyond the difficulties and criticisms attached to the term 'comparative religion'.

While the division between the two disciplines of Religious Studies and Philosophy is commonplace in Western academia, this bifurcation does not necessarily apply in non-western settings, where religion and philosophy often tend to be integrated. As a result, when the disciplines are virtually mutually exclusive, as in the west, a full appreciation of non-western approaches to both religion and philosophy is not easily attained, and other problems, such as false distinctions and exclusions, often occur. This workshop, in addressing such issues, was not an exercise in inter-religious dialogue, which occurs only among believers and practitioners; nor was it an apologetic undertaking where one religion would maintain dominance. Instead, it was an academic activity, initiated with the goal of re-examining ideas that may have been misappropriated or otherwise excluded in earlier comparative studies.

Thus, another central interest in the workshop was that of envisaging the ways that comparative philosophy and religion would be changed if the concepts and categories of non-western philosophies and religions were taken as the primary terms of reference. It also supported the exploration of whether the division between the two in the west has served to narrow the horizons of much contemporary western philosophy in a way that excludes 
modes of thinking that may not be amenable to its systems of classification. In doing so, it also acknowledged that the western-based academic study of religions has often tended, in an in-depth study of a particular religion, to focus narrowly on one aspect, or to make grandiose claims of similarity with non-western religions, based on broadly organized typologies of a phenomenological nature. This has often led to vague generalizations or inaccurate reductions to western constructs. In response, the workshop encouraged a re-examination within Comparative Philosophy and Religious Studies of a number of ideas that have often previously been taken for granted. In this spirit, the conference also encouraged interdisciplinary discussion between scholars working in a variety of cultural, religious studies, and philosophical fields.

In another respect, however, this project sought to refine and even replace accustomed and possibly erroneous understandings of the 'other'. It is imperative to avoid such pitfalls as simply superimposing familiar categories onto another tradition in order to achieve a comfortable synthesis; yet at the same time, in venturing into such unfamiliar terrain, one needs also to examine more familiar traditions from the perspective of this 'other', and thereby reveal presuppositions that are often taken for granted. This may well foster an awareness of incongruities within one's own paradigms that might otherwise go unnoticed.

The workshop was conducted with full awareness of the post-colonial critique of such enterprises. In addition, the overall aim of the project was not to reach a final solution, or to recommend a definitive method or procedure. It had a more modest endeavour of stimulating constructive discussion, which all involved hope that the resulting volume would stimulate. To that end, it probably raised more demanding issues and questions than it solved, but it nevertheless served to initiate many productive ideas and animated discussions as to a number of further exploratory projects along similar lines.

\section{Globalization}

My proposal is that all the critical practices listed above will need continued application today, with even greater attentiveness. This is in relation to external rather than internal causes. I introduce this because today, in many ways, globalization is now acknowledged as the new form of colonization, bringing with it an even more insidious rhetoric and tactics that conceal its predatory manoeuvres in the cause of capitalist markets. Both 
Chandra Talpade Mohanty and Gayatri Spivak, in their early studies in the 1980s, documented the continued disenabling effects of postcolonialism, specifically in regards to women, though they were not unaware of similar debilitating effects - in both economic, and educational areas - on lower classes and castes of men. More recently, in Mohanty (2003), and Spivak (2004), they both admit that this approach, given the recent exigencies of global capitalism, was not totally adequate. They made a decision to detail the international initiatives of globalization that surpassed postcolonial abuses. They also began to document their attempts to counter its effects by undertaking on-site activist and educative projects, rather than just theorizing about them. As Mohanty observes:

I wish to better see the processes of corporate globalization and how they recolonize women's bodies and labor. We need to know the real and concrete effects of global restructuring on raced, classed, national, sexual bodies of women in the academy, in workplaces, streets, households, cyberspaces, neighbourhoods, prisons, and social movements. (Mohanty 2003, 516.)

It has also become obvious that tertiary education itself is being commodified according to the standards of global business as a result of neo-conservative interference. It is extremely distressing when job advertisements list the need for a new President/CEO of a university. Students are often referred to as 'clients', who are purchasing education as a product. They demand satisfaction in the form of ' $\mathrm{A}$ ' grades. Professors are asked to solicit funds from industry or other sources to fund their research. They are also required to make their research relevant to social and economic interests. Finally, professors are judged on their 'output', quantified by their article submissions to specific standardized journals. Such journals themselves are evaluated according to a specific code that indicate levels of excellence.

Universities and departments are then rated according to such numeric scales. These facts and figures utterly fail as a mode of appraisal for disciplines in the human sciences, such as Religious Studies and Comparative Religion. As a British critic of this trend, Professor Stefan Collini of Cambridge University, remarks: 'The overriding aim is to bring the universities to heel: to change their character, to make them conform to market ideology [...]. Profit is the only indefeasible goal, competition is the only effective mechanism.' (Collini 2013, 12.) Collini's caution is that all university-based scholars need to pay attention to the structures of power and manipulation in which they could easily become more deeply entangled. 


\section{Conclusion}

While this development has not as yet totally reduced professors to being cogs in the wheel of capitalist profiteering, all scholars of Religious Studies, including those in Comparative Religion, need to be on their guard for a number of reasons. The basic justification for this suspicion is that, in such a business-oriented climate, their discipline is not among those subjects that are regarded as of particular worth in contemporary society. There seems to be a total lack of awareness on the part of the bureaucrats who are often determining university policy that a discipline such as Comparative Religion could be of immeasurable value. This is because, if taught from the perspectives that this paper has proposed, it is one of the few academic subjects that contribute to an understanding of the religions of the world - a much overlooked resource in today's pluralistic societies. At the same time, however, scholars also need to be constantly alert to the interactive and evershifting societal patterns that result today from increasing migration refugee populations. This steady stream of displaced persons challenges the former stark divisions into the artificially separate streams of study in Comparative Religion, such as those of eastern and western religions. Today these academic partitions need to be more flexible in their response to the diverse patterns of religious affiliation, which defy easy geographic assignation. Obviously, such rearrangements in population differ from country to country. As a result, there is no longer room for a facile generalization where east and west feature as a definitive binary, nor for any appeal to a universal template of a typology of religions that serves as a regulative ideal for Comparative Religion.

What is needed today is an awareness that there is no entirely uncompromised or ideal position today from which to undertake the study of Comparative Religion. On the one hand, no-one can invoke the discredited notion of the study of religion as being sui generis. On the other hand, as is obvious from the above discussion, no-one can presume that religion is unscathed by capitalistic and political interests. Accepting these presuppositions would foster a healthy self-reflexivity that acknowledges the 'discontents' that have beset civilization in ways that Freud did not recognize - especially in its relation to its colonial exploitation. It would also encourage an honest appraisal of the expropriations of resources, both human and material, being undertaken by the contemporary forces of globalization, from which Comparative Religion is not exempt. In order to adopt such a stance, Comparative Religion needs to pay more attention to other disciplines, such as anthropology, that have endeavoured to introduce such a critical perspective. Another helpful intervention would be the careful reading 
of recent works that take globalization to task. This has been undertaken by theorists in many different fields of study, e.g., Saskia Sassen (1998), Marguerite Waller and Sylvia Marcos (2005), Arjun Appadurai (2005), and George Rupp (2006). Their analyses and recommendations could support a continued rethinking of the terms of reference of Comparative Religion, as it endeavours to undertake research in re-envisioned ways. These new approaches neither succumb to banal adaptations of a marketplace mindset and terminology, nor do they acquiesce to compromise in relation to definitions and categories. These would constitute the hallmarks of the type of vibrant critical awareness needed to maintain the integrity of the discipline of Comparative Religion.

Bibliography

Almond, Philip C.

1988 The British Discovery of Buddhism. Cambridge: Cambridge University Press.

1992 The End of 'Religious' Pluralism. - N. Habel (ed.), Religion and Multiculturalism in Australia, 47-55. Adelaide: Australian Associates for the Study of Religion.

Appadurai, Arjun (ed.)

2005 Globalization. Durham NC: Duke University Press.

Asad, Talal

1993 Genealogies of Religion: Disciplines and Reasons of Power in Christianity and Islam. Baltimore, MD: Johns Hopkins University Press.

Balagangadhara, S. N.

1994 'The Heathen in his Blindness...': Asia, The West and the Dynamic of Religion. Leiden: Brill.

Bell, Diane

1994 Daughters of the Dreaming. Minneapolis, MN: University of Minnesota Press.

Butler, Judith

1990 Gender Trouble. New York, NY: Routledge.

Chakrabarty, Dipesh

1992 Postcoloniality and the Artifice of History: Who Speaks for 'Indian' Pasts? - Representations 37, 1-26. 
2000 Provincializing Europe: Postcolonial Thought and Historical Difference. Princeton, NJ: Princeton University Press.

\section{Chakravarti, Uma}

1989 Whatever Happened to the Vedic Dasi? Orientalism, Nationalism and a Script From the Past. - Kumkum Sangari \& Sudesh Vaid (eds), Recasting Women: Essays in Colonial History, 27-87. New Delhi: Kali for Women.

\section{Chatterjee, Partha}

1989 Colonialism, Nationalism and Colonialized Women: The Contest in India. - American Ethnologist 16 (4): 622-33.

\section{Chidester, David}

1996 Savage Systems. Charlottesville, VA: University of Virginia Press.

\section{Clifford, James}

1988 The Predicament of Culture: Twentieth-century Ethnography, Literature and Art. Cambridge, MA: Harvard University Press.

\section{Collini, Stefan}

2013 Sold Out. - London Review of Books 35 (20), 3-13.

\section{Das, Veena}

1986 Gender Studies, Cross-Cultural Comparison and the Colonial Organization of Knowledge. - Berkshire Review 21, 58-76.

\section{Donaldson, Laura E.}

1992 Decolonizing Feminisms: Race, Gender, and Empire Building. Chapel Hill, NC: University of North Carolina Press.

Donaldson, Laura E. \& Pui-Lan Kwok (eds)

2002 Postcolonialism, Feminism and Religious Discourse. New York/London: Routledge.

\section{Dube, Musa W.}

2002 Postcoloniality, Feminist Spaces and Religion. - Laura E. Donaldson and Pui-Lan Kwok (eds), Postcolonialism, Feminism and Religious Discourse, 100-120. New York/London: Routledge.

\section{Fitzgerald, Timothy}

2000 The Ideology of Religious Studies. New York, NY: Oxford University Press.

2001 A Response to Saler, Benavides, and Korom.-Religious Studies Review, 27 (2), 110-5.

\section{Gross, Rita}

1977 Androcentrism and Androgyny in the Methodology of History of Religions. - Beyond Androcentrism: New Essays on Women and Religion, 7-21. Missoula. MT: Scholars Press. 


\section{Inden, Ronald}

1986 Orientalist Constructions of India. - Modern Asian Studies 20 (3), 401-46.

1990 Imagining India. Bloomington, IN: Indiana University Press.

\section{Joy, Morny}

2000 Beyond a God's-Eye View: Alternative Perspectives in the Study of Religion. - Armin W. Geertz \& Russell T. McCutcheon (eds), Perspectives on Method and Theory in the Study of Religion. Adjunct Proceedings of the 17th Congress of the International Association for the History of Religions, 110-40. Leiden: Brill.

2003 Postcolonialism and Gender Reflections. - Ursula King \& Tina Beattie (eds), Challenges to Method in Religion, 28-39. London: Continuum.

2008 Method and Theory in Religious Studies: Retrospect and Future Prospects. - Temenos, 43 (2), 65-88.

2012 Revisiting Postcolonialism and Religion. - Australian Religious Studies Review 25 (2), 102-22.

Joy, Morny (ed.)

2013 After Appropriation: Explorations in Intercultural Philosophy and Religion. Calgary: University of Calgary Press.

\section{King, Richard}

1999 Orientalism and Religion: Postcolonial Theory, India and 'the Mystic East'. London: Routledge.

King, Ursula \& Tina Beattie (eds)

2003 Postcolonialism and Gender Reflections: Challenges to Method in Religion. London: Continuum.

\section{Kwok, Pui-Lan}

2005 Postcolonial Imagination and Feminist Theology. Louisville, KY: Westminster John Knox Press.

\section{Lopez, Donald S.}

1998 Prisoners of Shangri-La: Tibetan Buddhism and the West. Chicago, IL: University of Chicago Press.

\section{Mandair, Arvind-Pal S.}

2009 Religion and the Specter of the West: Sikhism, India, Postcoloniality, and the Politics of Translation. New York, NY: Columbia University Press.

\section{Marcos, Sylvia}

2006 Taken from the Lips: Gender and Eros in Mesoamerican Religions. Leiden: Brill.

Marcos, Sylvia (ed.)

2010 Women and Indigenous Religions. Santa Barbara, CA: Praeger. 


\section{Marcus, Julie}

1992 A World of Difference: Islam and Gender Hierarchy in Turkey. St. Leonards, Australia: Allen \& Unwin.

\section{Mohanty, Chandra Talpade}

2003 Feminism Without Borders: Decolonizing Theory, Practising Solidarity. Durham, NC: Duke University Press.

Nandy, Ashis

1983 The Intimate Enemy: Loss and Recovery of Self Under Colonialism. Delhi: Oxford University Press.

\section{Narayan, Uma}

1997 Dislocating Cultures, Identities, Traditions, and Third World Feminisms. New York, NY: Routledge.

1998 Essence of Culture and a Sense of History: A Feminist Critique of Cultural Essentialism. - Hypatia 13 (2), 86-106.

\section{Radahakrishnan, $\mathbf{R}$.}

1996 Diasporic Mediations: Between Home and Location. Minneapolis, MN: University of Minnesota Press.

\section{Rupp, George}

2006 Globalization Challenged: Conviction, Conflict, Community. New York, NY: Columbia University Press.

\section{Said, Edward W.}

1978 Orientalism, New York, NY: Vintage Books.

Sangari, KumKum \& Sudesh Vaid (eds)

1990 Recasting Women: Essays in Indian Colonial History. New Brunswick, NJ: Rutgers University Press.

\section{Sassen, Saskia}

1998 Globalization and its Discontents. New York, NY: New York Press.

Scott, Joan Wallach

1999 Gender and the Politics of History. New York, NY: Columbia University Press.

\section{Spivak, Gayatri Chakravorty}

2004 Righting Wrongs. - South Atlantic Quarterly 103 (2-3), 523-81.

\section{Smith, Jonathan Z.}

1978 A Map Is Not a Territory. - Jacob Neusner (ed.), Studies in Judaism in Late Antiquity, vol. 23, 289-309. Leiden: Brill.

\section{Thapar, Romila}

1989 Ancient History and the Modern Search for Hindu Identity. - Modern Asian Studies 23 (2), 209-31. 


\section{Urban, Hugh}

2003 Tantra: Sex, Secrecy, Politics, and Power in the Study of Religion. Berkeley, CA: University of California Press.

\section{Visweswaran, Kamala}

1994 Fictions of Femininst Ethnography. Minneapolis: University of Minnesota Press,

Waller, Marguerite \& Sylvia Marcos (eds)

2005 Dialogue and Difference: Feminists Challenge Globalization. London: Palgrave Macmillan. 